\title{
Statistical Analysis of Main and Interaction Effects to Optimize Xylanase Production under Submerged Cultivation Conditions
}

\author{
P. Mullai (Corresponding author) \\ Department of Chemical Engineering, Annamalai University \\ Chidambaram - 608002, Tamilnadu, India \\ Tel: 91-4144-239-737 E-mail: pmullai@yahoo.in \\ N. Syed Ali Fathima \\ Department of Chemical Engineering, Annamalai University \\ Chidambaram - 608002, Tamilnadu, India \\ Eldon R. Rene \\ Chemical Engineering Laboratory, University of La Coruña \\ Alejandro de la Sota, 1, E-15071 La Coruña, Spain
}

\begin{abstract}
In recent years, xylanase has become an essential option for environmental friendly industrial biotechnological applications and there is a rising demand for large scale production. In this study, a Bacillus species 2129 was tested for the xylanase production under submerged cultivation conditions. Maximum xylanase activities were achieved using oat as the substrate and by optimizing process conditions such as substrate concentration, $\mathrm{pH}$ and nitrogen source using statistically significant design of experiments, employing the response surface methodology (RSM) concept. Under optimized conditions there was an $8 \%$ increase in the enzyme activity and results from statistical approximation in the form of analysis of variance (ANOVA) shows that the squared effects of the variables were significant than both the main and interaction effects.
\end{abstract}

Keywords: Oat, Xylanase production, Response surface methodology, Optimization

\section{Introduction}

Xylanase is a hemi - cellulolytic polysaccharide consisting of 1,4 linked $\beta-D-x y l o$ pyranose residues, most commonly used for beer and juice clarification, pre-bleaching of kraft pulp, improving digestibility of animal feed, bread making and degumming of vegetable fibers such as jute ramie and hemp (Senior et al., 1992; Bocchini et al., 2005). The main constituents of microbial xylanolytic enzyme system are xylanase (endo-1,4- $\beta$-xylanase) and $\beta$-xylosidase ( $\beta-\mathrm{D}-\mathrm{xyloside}$ xylohydrolase) (Heck et al., 2005). Over the last few years, interest in xylanase has increased rapidly in paper and pulp industries due to their bleaching potential. Xylanases have a worldwide market of around 200 million US $\$$ and the widespread use of xylanase in commercialized industrial applications requires extensive studies to optimize their production capability (Sonia et al., 2005). There has been extensive lab and pilot scale studies that have dealt with their production, purification, recovery and characterization (Jain, 1995; Sa-Pereira et al., 2002; Seyis and Aksoz, 2005; Shah and Madamwar, 2005). On the other hand, very few studies have reported their product optimization (Narang et al., 2001; Senthilkumar et al., 2005; Heck et al., 2005). Commercial mass production of xylanase can be quintessentially done by either submerged or solid state fermentation (Pandey, 1992; Bocchini et al., 2005), their effectiveness has been often consociated with process conditions and physico-chemical factors of prior significance. However the driving force has been to ideally produce quick and high quality xylanase from simple and inexpensive substrates. Most of the researches have been targeted on using residues/wastes from agro and food industry, thereby restricting the socio-economics related to environmental pollution. These residues contain nearly 20-30\% hemicellulosic material that can be efficaciously used for the production of xylanase by microorganisms (Milagres et al., 
2004). The most commonly used substrates so far are; rice bran, sugarcane baggase, wheat straw, wheat bran, corn crop, rumen, sorghum straw and cassava peel (Alam et al., 1994; Wang et al., 2003; Sonia et al., 2005; Oliveira et al., 2006).

In this study, commercially available Oat was used as the substrate for the production of xylanase under submerged conditions. Oat grains (Avena sativa) are high in carbohydrates and contain about $13 \%$ protein and $7.5 \%$ fat. Studies that have reportedly used oat as the substrate for the production of xylanase are sparse (Oliveria et al., 2006). Diversified generic species of microorganisms have proven to be carriers of rich source of xylanase enzyme, especially Bacillus species which can secrete high levels of extra cellular xylanase. The amount of nitrogen also plays a vital role in enhancing the rate of enzyme production. $\mathrm{NH}_{4} \mathrm{NO}_{3}, \mathrm{NaNO}_{3}$ and $\left(\mathrm{NH}_{4}\right)_{2} \mathrm{SO}_{4}$ have been used essentially as the nitrogen source (Abdel-Sater and El-Said, 2001). Seyis and Aksoz (2005) used a mixture of $\mathrm{NH}_{4} \mathrm{SO}_{4}$ and urea and found synergistic increase in xylanase activity. For successful implementation of this new substrate, process parameters such as $\mathrm{pH}$, temperature, substrate concentration, cultivation and aeration time has to be optimized in appropriate reactor configurations. Though there are different optimization tools, factorial experiments and response surface methodology provides maximum information based on statistical principles by performing a minimum number of experiments (Montgomery, 1991).

This paper reports the optimization of substrate concentration, $\mathrm{pH}$ and nitrogen source for enhanced production of xylanase by a Bacillus species under submerged fermentation conditions.

\section{Materials and methods}

\subsection{Microbial strain}

The microbial culture used in this study was Bacillus sp. 2129, obtained from National chemical laboratory (NCL), Pune, India. Stock cultures were maintained on slants of nutrient agar medium at $4{ }^{\circ} \mathrm{C}$ and were periodically sub cultured to sustain microbial activity.

\subsection{Media composition}

The minimal medium used in this study had the following composition (per liter): beef extract - $1 \mathrm{~g}$, peptone - $1 \mathrm{~g}$ and Sodium chloride - $0.5 \mathrm{~g}$. Oat, obtained commercially from Quakers Company was used as the substrate (carbon source) at varying concentrations $(0.52-2.87 \%)$. All other chemicals used in this study were of analytical reagent grade purchased from Sigma Laboratories (India). The values of $\mathrm{NH}_{4} \mathrm{Cl}$ and Oat concentration are expressed in \%, in (weight/volume) basis.

\subsection{Experimental study}

Experiments were conducted in $250 \mathrm{ml}$ Erlenmeyer flasks fitted with butyl rubber stoppers having a working volume of $100 \mathrm{ml}$. The individual experimental flasks containing the media were sterilized at $15 \mathrm{psi}, 121^{\circ} \mathrm{C}$ for 20 minutes prior to inoculation. Bacillus species, maintained on nutrient agar slants were grown for 3 days at $30 \pm 1{ }^{\circ} \mathrm{C}$. After sufficient growth, $10 \mathrm{ml}$ of distilled water was aseptically added to each agar slants. Through mild scrapping with a sterilized inoculation loop and by periodic shaking, the colonies were made to suspend. For growth, $200 \mu 1$ of this suspension was aseptically transferred and provided as the inoculum to the $100 \mathrm{ml}$ media. The Bacillus strain was grown in experimental flasks kept in a rotary shaker $(150 \mathrm{rpm})$ at $30 \pm 1^{\circ} \mathrm{C}$ and sample aliquots were withdrawn at equal intervals (12 hrs) for measuring xylanase activity.

\subsection{Enzyme activity measurements}

Xylanase activity was measured by monitoring the reducing sugar concentration released as xylose by the dinitrosalicylic acid (DNS) method (Miller, 1959). The samples were centrifuged at $7200 \mathrm{rpm}$ for 15 mins and used for analysis. $0.1 \mathrm{ml}$ of this sample was mixed with $0.9 \mathrm{ml}$ of birchwood xylan solution $(5 \mathrm{~g} / \mathrm{l})$ in acetate buffer $(0.1 \mathrm{M})$ having a $\mathrm{pH}$ of 5.0 at $60^{\circ} \mathrm{C}$ for 10 mins. The absorbance was read at $550 \mathrm{~nm}$ using a UV/Vis spectrophotometer (Shimadzu, Japan). A unit of xylanase activity was described as the amount of enzyme producing $1 \mu \mathrm{mol}$ of reducing sugar equivalent to xylose per minute under standard test conditions.

\subsection{The $2^{3}$ central composite design}

To investigate the effect of parameters such as substrate concentration, $\mathrm{pH}$ and ammonium chloride concentration on the enzyme activity, experiments were carried out according to the full factorial central composite design (CCD) as described by Montgomery, (1991). The three steps of this experimental design include statically designed experiments, estimating the coefficients in a mathematical model and predicting the response and checking the applicability of the model. A $2^{3}$ CCD for three independent variables, each investigated at five levels with six star points and six replicates at the central point was experimented to fit a second order polynomial model that required 20 experiments. The number of center point runs that the design specifies depends on certain inherent properties required for the design (Montgomery, 1991; Gopal et al., 2002). The start points represent new extreme (low and high) for each factor in the design (Techapun et al., 2002). To maintain rotatability, the value of $\alpha$ depends on the number of experimental runs in the factorial portion of the CCD. If the factorial is a full factorial with " $\mathrm{k}$ " factors, then 


$$
\alpha=\left[2^{k}\right]^{1 / 4}
$$

The dependent variable (response) selected for this study was the enzyme activity, expressed in $\mathrm{U} / \mathrm{ml}$, while the independent variables chosen were oat concentration (X1), media pH (X2) and ammonium chloride concentration (X3). The range and levels of these experimental variables are given in Table 1.

According to the CCD theory, the response variable can be approximated to the process variables by a second order polynomial model of the form:

$$
\mathrm{Y}=\mathrm{b} 0+\mathrm{b} 1 \mathrm{X} 1+\mathrm{b} 2 \mathrm{X} 2+\mathrm{b} 3 \mathrm{X} 3+\mathrm{b} 11 \mathrm{X} 12+\mathrm{b} 22 \mathrm{X} 22+\mathrm{b} 33 \mathrm{X} 32+\mathrm{b} 12 \mathrm{X} 1 \mathrm{X} 2+\mathrm{b} 13 \mathrm{X} 13+\mathrm{b} 23 \mathrm{X} 2 \mathrm{X} 3+\varepsilon
$$

Where $\mathrm{Y}$ is the measured response, bo the intercept term, $\mathrm{b} 1-3$ are the measures of the effects of variables (coefficients) and $\varepsilon$ is the experimental error. The test factors were coded according to the following equation.

$$
x_{i}=\frac{X_{i}-X_{i}^{x}}{\Delta X_{i}}
$$

Where $\mathrm{x}_{\mathrm{i}}$ is the coded value, $\mathrm{X}_{\mathrm{i}}$ is the actual value of the $\mathrm{i}^{\text {th }}$ independent variable, $\mathrm{X}_{\mathrm{i}}{ }^{\mathrm{X}}$ is the actual value of the $\mathrm{i}^{\text {th }}$ independent variable at the center point and $\Delta X_{i}$ is the step change value. The MINITAB 14 (PA, USA) software was used for regression and graphical analysis (Response surface and contour plots) of the data obtained. Analysis of variance (ANOVA) was used to estimate the statistical parameters. The predicted values were calculated from the regression model derived from the coefficients of the model and variations were explained by the determination coefficient ( $\mathrm{R}^{2}$ values).

\section{Results and Discussion}

Experiments were carried out to optimize the effects of various process variables such as initial substrate (oat) concentration, $\mathrm{pH}$ and ammonium chloride $\left(\mathrm{NH}_{4} \mathrm{Cl}\right)$ concentration for xylanase production according to the statistically significant $2^{\mathrm{k}}$ full factorial central composite design (CCD). Furthermore, the results were analyzed by analysis of variance (ANOVA). This assisted in elucidating the main, squared and interaction effects among the process variables and their influence on the measured enzyme activity. All experiments were carried out in sequential order as specified by the design, in duplicate and the average values of measured enzyme activity were taken as the response variable. Figure 1 depicts the main effects of process variables on the enzyme activity, while Table 2 describes the process conditions and the experimentally measured enzyme activity. It was found that these profiles neither showed a single increasing or decreasing trend, but displayed a combination of both increasing and decreasing trends, suggesting the existence of an optimum condition within the range of experimental study. When the substrate concentration was increased from $0.5 \%$ to $1.7 \%$ the enzyme activity increased from a value of 0.23 to $1 \mathrm{U} / \mathrm{ml}$, and then decreased to around $0.2 \mathrm{U} / \mathrm{ml}$ at a substrate concentration of $2.8772 \%$. With the increase in $\mathrm{pH}$ concentration from low to high levels, the enzyme activity decreased from a value of 2.2 to about $0.45 \mathrm{U} / \mathrm{ml}$ and then the enzyme activity progressively increased to a value of $2.2 \mathrm{U} / \mathrm{ml}$. Similarly, on increasing the $\mathrm{NH}_{4} \mathrm{Cl}$ concentration, the enzyme activity first showed a declining trend and then increasing trend at a concentration of $0.6681 \%$. The maximum enzyme activity was achieved for the substrate concentration of $1.7 \%, \mathrm{pH}$ of 6.807 and $\mathrm{NH}_{4} \mathrm{Cl}$ concentration of $0.5 \%$ (run number 11). The xylanase production was between $0.48-0.49 \mathrm{U} / \mathrm{ml}$ in the medium with the three test variables at their central level. The carbon source used in this study is one of the major factors affecting the production of enzymes and their levels. The graphical representation of the interactions between process variables and their response called the response surface plots (RS plots) are presented at different levels of substrate concentration, $\mathrm{pH}$ and $\mathrm{NH}_{4} \mathrm{Cl}$ concentrations in Figures 2, 4 and 6 . Each contour plot showed an infinite number of combinations of the two test variables with the other variable maintained at ' 0 ' level. The peaks and curvature indicated the maximum enzyme activity in the RS plots. The shapes of the surfaces, circular (or) elliptical indicated whether the interactions among different variables were significant or not. In general, the RS plots can be dome shaped, inverted ' $U$ ' shaped, some with a saddle point and some do not show any regular variation with increase / decrease in variables. Each RS plot is further complimented with contour diagrams (Figures 3,5 and 7) that reveal information on the variation of response on a XY plane. The surface confined to the smallest curve of the contour diagram suggested the location of an optimum operating condition under the experimental condition. The graphical illustrations in Figures 2 and 3 reveal that the enzyme activity was at its maximum under the following condition: high $\mathrm{pH}$ and low levels of $\mathrm{NH}_{4} \mathrm{Cl}$, high $\mathrm{NH}_{4} \mathrm{Cl}$ and low $\mathrm{pH}$. These plots showed a shallow surface of an optimum condition at the intermediate levels and hills at extreme operating conditions. This interaction behavior causes the optimal level of one variable to change in response to changes in other variables. Mathematically, a saddle point (Figure 4) is a point of a function with two or more variables which is at stationary point but not extremum. At such point, the surface could resemble a saddle point that curves up in one direction and curves down in one or several other directions. The saddle shaped surface does not have a unique optimum; instead it represents maximum value of the response variable in one direction, but a minimum in one or several directions. As shown in Figure 4, the rate of increase in enzyme activity with an increase in value of $\mathrm{pH}$ above its saddle point is greater than the rate of increase in 
enzyme activity when substrate concentration is increased/decreased from the saddle point. Similarly, Figure 6 shows that higher enzymatic activity is achieved by decreasing $\mathrm{NH}_{4} \mathrm{Cl}$ below its saddle point value than by increasing it above its saddle point value.

Further, the contour plot (Figure 3) depicts concentric elliptical ridges within the design boundary, and this runs diagonally from the lower right to the upper left end. These types of contours passes through the steepest ascent of enzyme activity and the optimum operating conditions and in direction of maximum decline of the response with respect to increasing or decreasing values of the process variables. The interactions between substrate concentration and $\mathrm{pH}$ (Figure 5) showed a rather complex behavior in comparison to those explained earlier. At low and high levels of $\mathrm{pH}$, increasing the substrate concentration increased the enzyme activity up to a maximum and then decreased their values. However at intermediate levels of $\mathrm{pH}$, irrespective of the values of substrate concentration, there existed a region where neither an increasing nor decreasing trend in the enzyme activity was noticed. These are represented by complex saddle type contour plot as shown in Figure 5. Similar type of interactions was observed between $\mathrm{NH}_{4} \mathrm{Cl}$ and substrate concentrations (Figures 7). The non-elliptical nature of the contour plots depicts that there is no mutual interaction between the test variables. The experimental data was then analyzed statistically to obtain the following regression equation:

$$
\begin{gathered}
\mathrm{Y}_{\mathrm{EA}}=0.5048+0.0707 \mathrm{X}_{1}+0.111 \mathrm{X}_{2}-0.1734 \mathrm{X}_{3}-0.2556 \mathrm{X}_{1}^{2}+0.4564 \mathrm{X}_{2}^{2}+0.1504 \mathrm{X}_{3}^{2}-0.0284 \mathrm{X}_{1} \mathrm{X}_{2}+0.0227 \mathrm{X}_{1} \\
\mathrm{X}_{3}-0.3951 \mathrm{X}_{2} \mathrm{X}_{3}
\end{gathered}
$$

Where, $\mathrm{Y}_{\mathrm{EA}}-$ Response variable representing enzyme activity, $\mathrm{X}_{1}-$ initial substrate concentration, $\mathrm{X}_{2}-\mathrm{pH}$ and $\mathrm{X}_{3}-$ $\mathrm{NH}_{4} \mathrm{Cl}$ concentration.

The determination coefficient value for this model equation was reasonably good under the experimental condition used in this study. The ANOVA result for the quadratic model is given in Table 3. In general the Fischer's variance ratio, the $\mathrm{F}$ value should be higher than the low probability, $\mathrm{P}$ values, for the predictions to be significant. This statistical analysis was done at the $95 \%$ confidence interval by the software, MINITAB 14 . In this study among the main, squared and interaction effects of the variables on the enzyme activity, the squared effects played a major role for enzyme activity (F value of 7.61, $\mathrm{P}$ value of 0.006 than the main and interaction effects.

To understand the pattern of interaction and to envision synergistic and antagonistic effects between test variables, the student's t-test and P values were tabulated using the software as shown in Table 4. The larger magnitude of $t$ value (either \pm ) and smaller $\mathrm{P}$ value, the more significant is the corresponding coefficient (Liu et al., 2004). Student's t-test was employed to determine the knowledge of the error mean square that is essential in testing the significance of the estimated coefficient of the regression equation. The student's $t$-test value can be obtained by dividing each coefficient by its standard error. A large ' $t$ ' value implies that the coefficient is much greater than its standard error. The squared effects of $\mathrm{pH}$ and substrate concentration $(\mathrm{P}-0.003$ and 0.055$)$ had a major edge over other interaction and main effects. However the values of " $t$ " and their sign imply the impact of their effects on the enzyme activity. The squared effects of $\mathrm{pH}$ increased the enzyme activity $(\mathrm{t}=3.87)$, while the effects of substrate concentration ( $\mathrm{t}$ value of -2.167$)$ decreased the enzyme activity. On the other hand, the interaction effects between $\mathrm{pH}$ and $\mathrm{NH}_{4} \mathrm{Cl}$ also showed negative effects on the enzyme activity with low $\mathrm{P}$ values (0.032). All the other coefficients ( $t$ values) were found to be insignificant. More precisely, the results from this study relied more on the square and interaction effects of the process variables than the main effects, while complex interactions were manifested with a statistical significance.

The optimum sets of operating conditions were obtained by solving the regression equation using the Monte Carlo simulation technique. The optimal values were first obtained in coded units $(0.1523,0.0934$ and 0.6435$)$ and then converted to the respective uncoded (real) units using the formulae described in Montgomery (1991). The optimal values of initial substrate concentration, $\mathrm{pH}$ and ammonium chloride concentration were $1.8066 \%, 4.193$ and $0.5645 \%$ respectively. At these optimal conditions the enzyme activity was $2.388 \mathrm{U} / \mathrm{ml}$, which was higher than the activity observed during regular experimentation. Nissen et al., (1992) have suggested an optimal $\mathrm{pH}$ of 6-8 for increased production of xylanase. Horikoshi and Atsukawa (1973) were the first to report xylanase from Bacillus sp., which was also active under high $\mathrm{pH}$ conditions. In this study, the model predicts the optimal concentration of xylanase production to be in lower $\mathrm{pH}$ range. Furthermore, the coded values were substituted in the regression equation to obtain the predicted enzyme activity, and a good correlation between the measured and predicted responses was noticed, as seen from their $\mathrm{R}^{2}$ value $(0.8950)$. The findings of the present investigation compare well with the work of Ellaiah et al., (2002) on response surface optimization of the critical medium components for the production of alkaline protease by a newly isolated Bacillus species. Similarly, CCD techniques have been used to optimize maximum xylanase yields by Schizophyllum commune and Thermomyces $s p$ with activity of $5.74 \mathrm{U} / \mathrm{ml}$ and $2.74 \mathrm{U} / \mathrm{ml}$ under submerged conditions (Haltrich et al., 1993; Purkarthofer et al., 1993). Senthil kumar et al., (2005) optimized xylanase yield at 1024 U/gm of wheat bran using Aspergillus fischeri under solid state fermentation conditions. The optimum condition predicted by the model was verified by carrying experiments in triplicate using the same procedure outlined earlier to monitor the 
enzyme activity. The model predicted enzyme activity value agreed well with the experimental result with an error of $7.6 \%$.

\section{Conclusions}

This research work demonstrates that response surface methodology can be a powerful and simple tool to effectively analyze the results and to determine optimal conditions for xylanase production.

Laboratory scale batch experiments were performed with commercially available oat as the substrate in a mineral salt media under controlled conditions. The results from this study showed that under optimum values of substrate concentration: $1.8066 \%$, pH: 4.913 and $\mathrm{NH}_{4} \mathrm{Cl}: 0.5645 \%$, the enzyme activity would be $2.388 \mathrm{U} / \mathrm{ml}$. Further analysis with surface plots reveal that pairing factors produce saddle point response after a critical value indicating that some of the interactions were insignificant.

\section{Acknowledgement}

The authors of this paper would gratefully thank the Faculty of Engineering and Technology, Annamalai University, India for their continued support through research grants and Prof T. Swaminathan, Environmental Management Research Laboratory, Department of Chemical Engineering, Indian Institute of Technology Madras for his research suggestions.

\section{References}

Abdel-Sater, M.A. \& El-Said, A.H.M. (2001). Xylan-decomposing fungi and xylanolytic activity in agricultural and industrial wastes. International Biodeterioration \& Biodegradation, 47, 15-21.

Alam, M., Gomes, I., Mohiuddin, G. \& Hoq, M.M. (1994). Production and characterization of thermostable xylanases by Thermomyces lanuginosus and Thermoascus aurantiacus grown on lignocelluloses. Enzyme and Microbial Technology, 16, 298-302.

Bocchini, D. A., Oliveira, O.M.M.F., Gomes, E. \& Da Silva, R. (2005). Use of sugarcane baggase and grass hydrolysates as carbon sources for xylanase production by Bacillus circulans D1 in submerged fermentation. Process Biochemistry, 40, 3653-3659.

Ellaiah, P., Adinarayana, K., Bhavani, Y., Padmaja, P. \& Srinivasulu, B. (2002). Optimization of process parameters for glucoamylase production under solid state fermentation by a newly isolated Aspergillus species. Process Biochemistry, 38, 615-620.

Gopal, M., Pakshirajan, K., \& Swaminathan, T. (2002). Heavy metal removal by biosorption using Phanerochaete chrysosporium. Applied Biochemistry and Biotechnology, 102, 227-237.

Haltrich, D., Preiss, M. \& Steiner, W. (1993). Optimization of a culture medium for increased xylanase production by a wild strain of Schizophyllum commune. Enzyme and Microbial Technology, 15, 854-860.

Heck, J.X., Flores, S.H., Hertz, P.F. \& Ayub, M.A.Z. (2005). Optimization of cellulase-free xylanase activity produced by Bacillus coagulans BL69 in solid-state cultivation. Process Biochemistry, 40, 107-112.

Horikoshi, K., \& Y. Atsukawa. (1973) Xylanase produced by alkalophilic Bacillus no. C-59-2. Agricultural and Biological Chemistry, 37, 2097-2103.

Jain, A. (1995). Production of Xylanase by Thermophilic Melanocarpus albomyces IIS-68. Process Biochemistry, 30, 705-709.

Liu, H.L., Lan, Y.W. \& Heng, Y.C. (2004). Optimal production of sulphuric acid by Thiobacillus thiooxidans using response surface methodology. Process Biochemistry, 39, 1953-1961.

Milagres, A. M. F., Santos, E., Piovan, T. \& Roberto, I.C. (2004). Production of xylanase by Thermoascus aurantiacus from sugar cane bagasse in an aerated growth fermentor. Process Biochemistry, 39, 1387-1391.

Miller, G. L. (1959). Use of dinitrosalicylic acid reagent for determination of reducing sugars. Analytical Chemistry, 31, 426-428.

Montgomery, D. C. (1991). Design and Analysis of Experiments, New York, NY: John Wiley \& Sons.

Narang S, Sahai V \& Bisaria VS. (2001). Optimization of xylanase production by Melanocarpus albomyces IIS68 in solid state fermentation using response surface methodology. Journal of Bioscience and Bioengineering, 91, 425-427.

Nissen, A.M., Anker, L., Munk, N. \& Lange, N. K. (1992). Xylanases for the pulp and paper industry". In "Xylans and Xylanases" (Eds: Visser, J., Beldman, G., Kusters-van Someren, M.A. \& Voragen, A.G.J.) Elsevier Science Publishers, Amsterdam, 325-338.

Oliveira, L.A., Porto, A.L.F., Elias, B. \& Tambourgi. (2006). Production of xylanase and protease by Penicillium janthinellum CRC 87M-115 from different agricultural wastes. Bioresource Technology, 97, 862-867. 
Pandey, A. (1992). Recent process developments in solid-state fermentation. Process Biochemistry, 27, $109-117$.

Purkarthofer, H., Sinner, M. \& Steiner, W. (1993). Cellulase-free xylanase from Thermomyces lanuginosus: Optimization of production in submerged and solid-state culture. Enzyme and Microbial Technology, 15, 677-682.

Sa-Pereira P., Costa-Ferreira M. \& Aires-Barros M. R. (2002). Enzymatic properties of a neutral endo-1,3 (4)-beta-xylanase Xyl II from Bacillus subtilis. Journal of Biotechnology, 94, 265-75.

Senior, D. J., Hamilton, J., Bernier, R. L. \& Dumanoir, J. R. (1992). Reduction in chlorine use during bleaching of kraft pulp following xylanase treatment. Tappi Journal, 11, 125-130.

Senthilkumar, S.R., Ashokkumar, B., Raj, K.C. \& Gunasekaran, P. (2005). Optimization of medium composition for alkali-stable xylanase production by Aspergillus fischeri Fxn 1 in solid-state fermentation using central composite rotary design. Bioresource Technology, 96, 1380-1386.

Seyis, I. \& Aksoz, N. (2005). Effect of carbon and nitrogen sources on xylanase production by Trichoderma harzianum 1073 D3. International Biodeterioration \& Biodegradation, 55, 115-119.

Shah, A.R. \& Madamwar, D. (2005). Xylanase production by a newly isolated Aspergillus foetidus strain and its characterization. Process Biochemistry, 40, 1763-1771.

Sonia, K. G., Chada, B.S. \& Saini, H.S. (2005). Sorghum straw for xylanase hyper-production by Thermomyces lanuginosus (D2W3) under solid-state fermentation. Bioresource Technology, 96, 1561-1569.

Techapun, C., Charoenrat, T., Watanabe, M., Sasaki, K., Poosaran, N. (2002). Optimization of thermostable and alkaline-tolerant cellulase-free xylanase production from agricultural waste by thermotolerant Streptomyces sp. Ab106, using the central composite experimental design. Biochemical Engineering Journal, 12, 99-105.

Wang, S.L., Yen, Y, H., Shih, I.L., Chang, A.C., Chang, W.T., Wu, W.C. \& Chai, Y.D. (2003). Production of xylanases from rice bran by Streptomyces actuosus A-151. Enzyme and Microbial Technology, 33, 917-925.

Table 1. Range and levels of process variables

\begin{tabular}{lccccc}
\hline \multicolumn{1}{c}{ Variable } & \multicolumn{5}{c}{ Range and level } \\
\cline { 2 - 6 } & $-\propto$ & $-\mathbf{1}$ & $\mathbf{0}$ & $\mathbf{+ 1}$ & $+\infty$ \\
\hline $\mathbf{X}_{\mathbf{1}}$, Substrate concentration & 0.5227 & 1 & 1.7 & 2.4 & 2.8772 \\
$\mathbf{X}_{\mathbf{2}}, \mathbf{p H}$ & 1.8068 & 3 & 4.75 & 6.5 & 7.6931 \\
$\mathbf{X}_{\mathbf{3}}, \mathbf{N H}_{\mathbf{4}} \mathbf{C l}$ concentration & 0.3318 & 0.4 & 0.5 & 0.6 & 0.6681 \\
\hline
\end{tabular}


Table 2. Enzyme activity measured at different combinations of substrate concentration, $\mathrm{pH}$ and $\mathrm{NH}_{4} \mathrm{Cl}$ concentration

\begin{tabular}{ccccc}
\hline Run No & Oat $(\%)$ & $\mathbf{p H}$ & $\mathbf{N H}_{\mathbf{4}} \mathbf{C l}(\%)$ & $\begin{array}{c}\text { Enzyme activity (U/ml) } \\
\text { Measured }\end{array}$ \\
\hline 1 & & & & 0.333 \\
2 & 1.000 & 3.000 & 0.400 & 0.280 \\
3 & 2.400 & 3.000 & 0.400 & 1.253 \\
4 & 1.000 & 6.500 & 0.400 & 1.788 \\
5 & 2.400 & 6.500 & 0.400 & 0.131 \\
6 & 1.000 & 3.000 & 0.600 & 0.869 \\
7 & 2.400 & 3.000 & 0.600 & 0.172 \\
8 & 1.000 & 6.500 & 0.600 & 0.096 \\
9 & 2.400 & 6.500 & 0.600 & 0.175 \\
10 & 0.523 & 4.750 & 0.500 & 0.070 \\
11 & 2.877 & 4.750 & 0.500 & 2.190 \\
12 & 1.700 & 1.807 & 0.500 & 2.082 \\
13 & 1.700 & 7.693 & 0.500 & 1.267 \\
14 & 1.700 & 4.750 & 0.332 & 1.274 \\
15 & 1.700 & 4.750 & 0.668 & 0.486 \\
16 & 1.700 & 4.750 & 0.500 & 0.480 \\
17 & 1.700 & 4.750 & 0.500 & 0.484 \\
18 & 1.700 & 4.750 & 0.500 & 0.490 \\
19 & 1.700 & 4.750 & 0.500 & 0.481 \\
20 & 1.700 & 4.750 & 0.500 & 0.492 \\
\hline
\end{tabular}

Table 3. Anova for the quadratic regression model for enzyme activity

\begin{tabular}{ccccccc}
\hline Source & $\begin{array}{c}\text { Degrees of } \\
\text { Freedom }\end{array}$ & $\begin{array}{c}\text { Seq } \\
\text { Sum of } \\
\text { square }\end{array}$ & $\begin{array}{c}\text { Adj } \\
\text { Sum of } \\
\text { square }\end{array}$ & $\begin{array}{c}\text { Adj Mean } \\
\text { Square }\end{array}$ & F Value & P Value \\
\hline Regression & 9 & 6.483 & 6.483 & 0.720 & & \\
Linear & 3 & 0.649 & 0.649 & 0.216 & 3.59 & 0.029 \\
Square & 3 & 4.575 & 4.575 & 1.525 & 1.08 & 0.401 \\
Interaction & 3 & 1.259 & 1.259 & 0.419 & 7.61 & 0.006 \\
Residual Error & 10 & 2.004 & 2.004 & 0.2004 & 2.09 & 0.165 \\
Lack-of-fit & 5 & 0.0001 & 0.0001 & 0.400 & & \\
Pure error & 5 & 8.488 & 8.488 & 0.00002 & & \\
Total & 19 & & & & & \\
\hline
\end{tabular}


Table 4. Significance test for main and interaction effects of the variable on enzyme activity measured under varying operating conditions

\begin{tabular}{ccccc}
\hline $\begin{array}{c}\text { Independent variables } \\
\text { (parameters) }\end{array}$ & Coefficient $(\boldsymbol{\beta})$ & $\begin{array}{c}\text { Standard } \\
\text { error }(\boldsymbol{\beta})\end{array}$ & 't'- value & P- value \\
\hline Constant & 0.5048 & 0.1826 & 2.765 & 0.020 \\
$\mathrm{X}_{1}$ & 0.0707 & 0.1211 & 0.584 & 0.572 \\
$\mathrm{X}_{2}$ & 0.1110 & 0.1211 & 0.916 & 0.381 \\
$\mathrm{X}_{3}$ & -0.1738 & 0.1211 & -1.435 & 0.182 \\
$\mathrm{X}_{1}{ }^{2}$ & -0.2556 & 0.1179 & -2.167 & 0.055 \\
$\mathrm{X}_{2}{ }^{2}$ & 0.4564 & 0.1179 & 3.870 & 0.003 \\
$\mathrm{X}_{3}$ & 0.1504 & 0.1179 & 1.275 & 0.231 \\
$\mathrm{X}_{1} \mathrm{X}_{2}$ & -0.0284 & 0.1583 & -0.179 & 0.861 \\
$\mathrm{X}_{1} \mathrm{X}_{3}$ & 0.0227 & 0.1583 & 0.143 & 0.889 \\
$\mathrm{X}_{2} \mathrm{X}_{3}$ & -0.3951 & 0.1583 & -2.496 & 0.032 \\
\hline
\end{tabular}

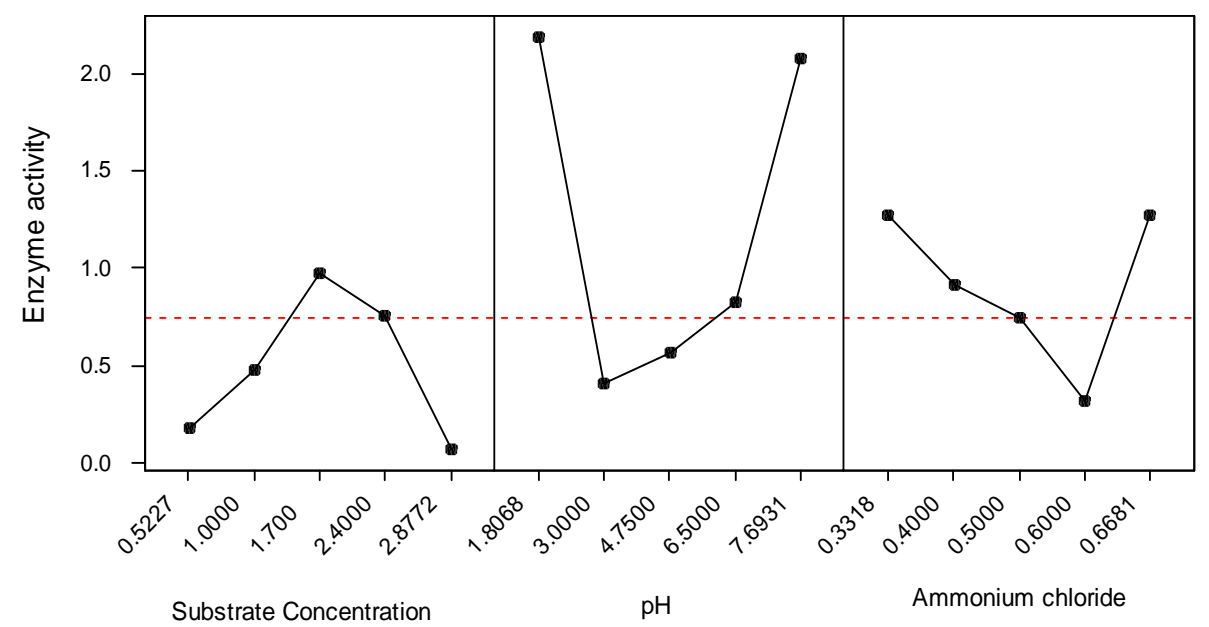

Figure 1. Main effects plot of process parameters on enzyme activity

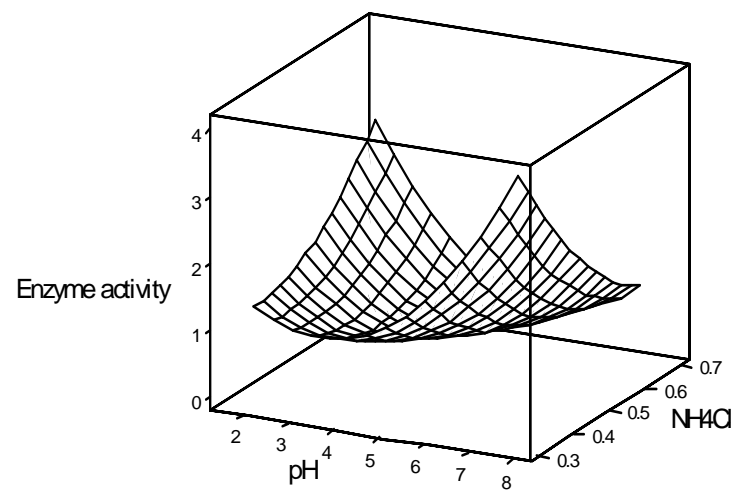

Figure 2. Response surface plot for enzyme activity at different ranges of $\mathrm{pH}$ and $\mathrm{NH} 4 \mathrm{Cl}$ concentrations 


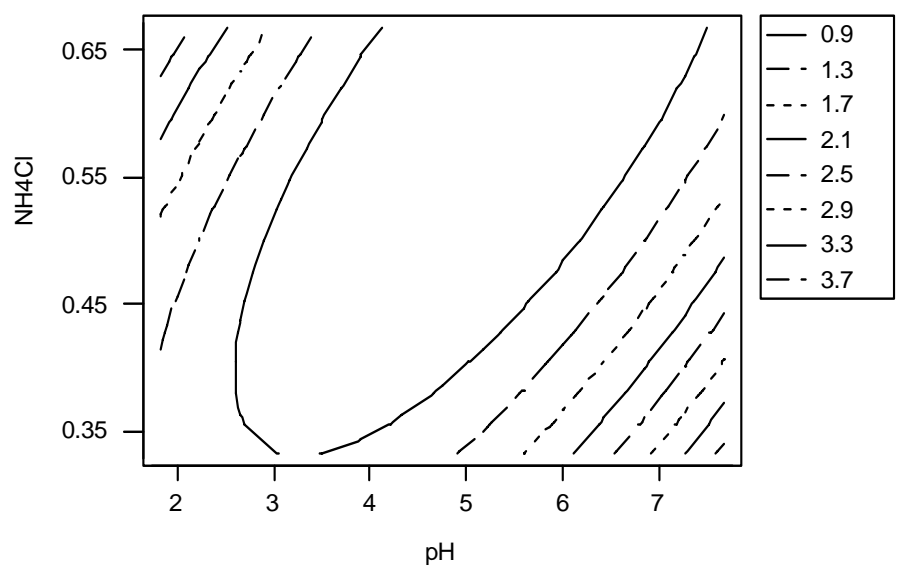

Hold values Substrat: 1.7

Figure 3. Contour plot for enzyme activity at different ranges of $\mathrm{pH}$ and $\mathrm{NH} 4 \mathrm{Cl}$ concentrations

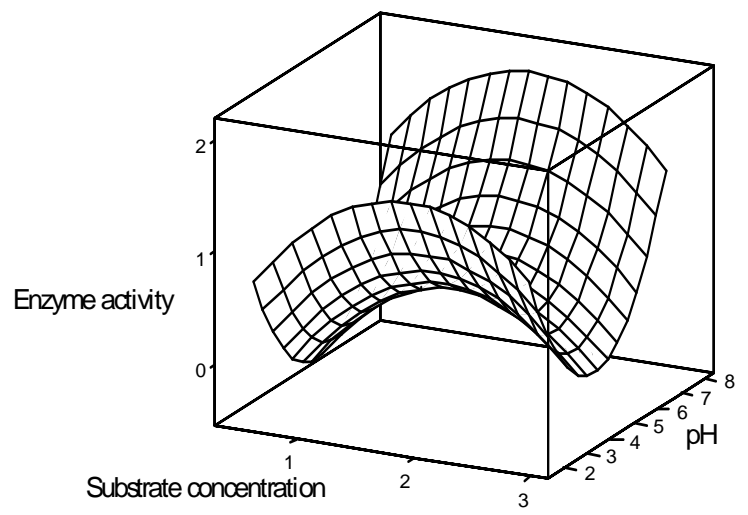

Figure 4. Response surface plot for enzyme activity at different ranges of substrate concentration and $\mathrm{pH}$

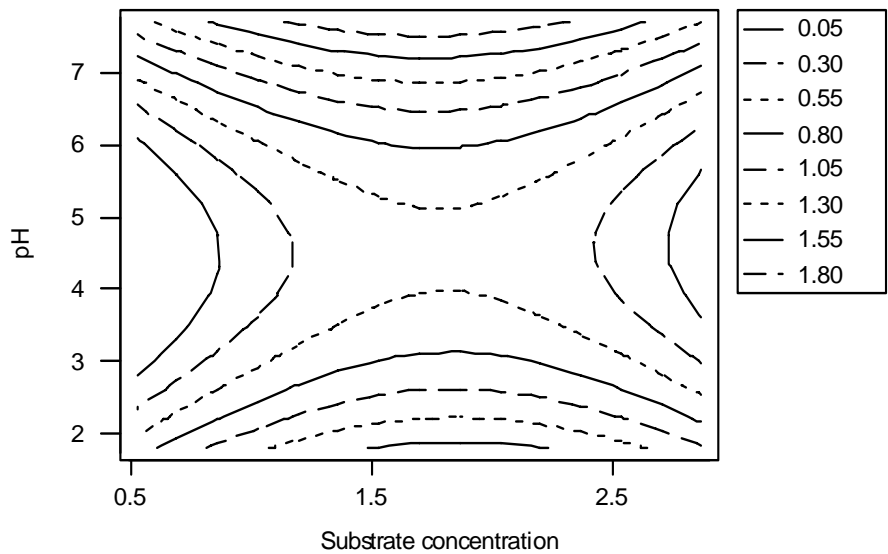

Hold values NH4Cl: 0.5

Figure 5. Contour plot for enzyme activity at different ranges of substrate concentration and $\mathrm{pH}$ 


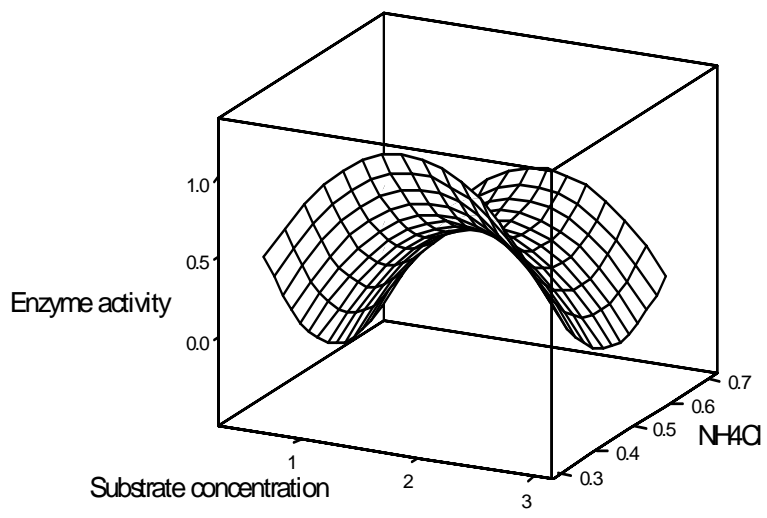

Figure 6. Response surface plot for enzyme activity at different ranges of substrate concentration and $\mathrm{NH} 4 \mathrm{Cl}$ concentrations

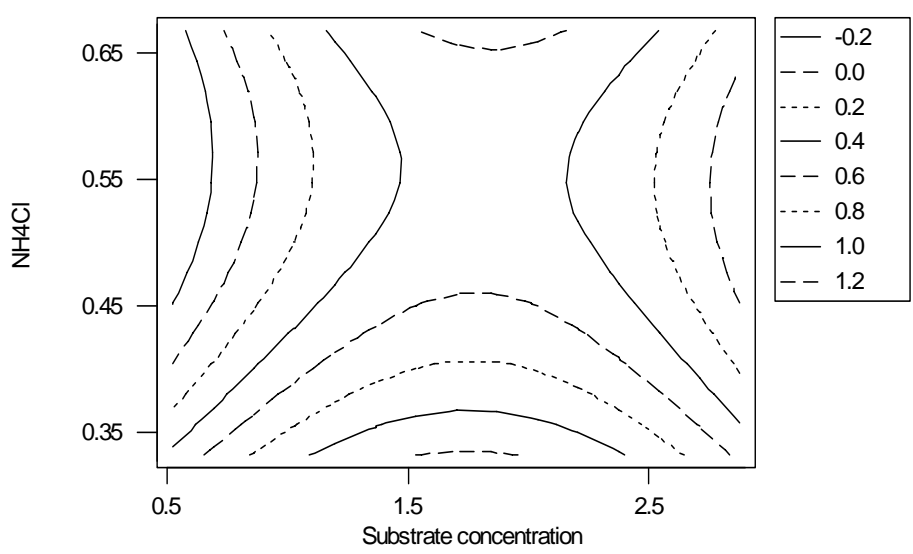

Hold values: $\mathrm{pH}: 4.75$

Figure 7. Contour plot for enzyme activity at different ranges of substrate concentration and $\mathrm{NH} 4 \mathrm{Cl}$ concentrations 